\title{
Conditions and Implementation of the Energy Policy of the Russian Federation
}

Abstract: The article is devoted to the issues relating to the energy policy of the Russian Federation, with a particular emphasis on its conditions, assumptions and implementation. The article also discusses the policy of diversifying transit routes for Russian gas, energy cooperation between Russia and the European Union, and the Russian strategy related to the export of gas to new world markets and its global expansion in this area.

KeYwords: Russia, Gazprom, Energy policy

\section{Introduction}

The foreign and security policy of the Russian Federation, apart from some traditional instruments of implementation, depends largely on energy resources. A key role in this matter is played by the dominant position of Russia in the global energy market, and some individual countries dependent on raw materials supplies from Russia. In this article, the most important aspects of the energy policy of the Russian Federation will be discussed in relation to its conditions, principles and their implementation. The article has been written mainly using the historic method, the comparative method, and content analysis.

The thesis developed in this chapter is the claim that since the collapse of the Soviet Union, the energy policy of Russia has been considered an important element 
of the country's foreign and security policy. The authorities of the Russian Federation, thanks to its energy policy instruments, have been building bilateral relations with particular countries and pursuing Russia's interests in the international arena. Russia has been using its dominant position in the energy market to strengthen its own position and to influence internal processes in particular countries. The effectiveness of these instruments has varied and to a large extent relies on making individual countries dependent on Russian supplies.

\section{Energy strategy of the Russian Federation}

The use of energy instruments in the foreign and security policy of Russia is expressly described in the current "Energy strategy of the Russian Federation until 2030". This document was adopted during a government meeting on 13 November 2009, when it replaced the previous strategy adopted on 28 August $2003^{1}$.

The document stressed that the main purpose of the country's energy policy is to intensely use rich raw material resources and the potential of the energy sector to achieve a balanced growth and maximum economic benefits, as well as to strengthen Russia's position in foreign markets. It highlighted that Russia holds one of the most important positions in the global energy market and that it is in its vital interest to further develop the production of energy resources and export them to foreign markets ${ }^{2}$.

In the Strategy, it was emphasized that with $12 \%$ of the global production of this raw material, Russia is a world leader in this aspect. The vast majority of this volume is sent to European countries, where Russia's market share is $30 \%$ approximately. It was also indicated that Russia is second in the world in terms of coal reserves (19\% of global resources) and has about $12 \%$ of the global trade in thermal coal. It was also emphasized that the atomic energy sector is crucial for the country's security, as Russian atomic energy represents $5 \%$ of the global market, $45 \%$ of the enriched uranium market, and $8 \%$ of the global market of natural uranium mining. It was also emphasized that Russia has the world's biggest natural gas resources (23\%), which play a key role in the European gas market and the individual markets of the Commonwealth of Independent States ${ }^{3}$.

\footnotetext{
Энергетическая стратегия России на период до 2030 года утверджена распоряжением Правительства Российской Федерачии от 13 ноября 2009 z. № 1715-p, https://minenergo. gov.ru/node/1026 (accessed: 21.02.2018).

2 Ibidem.

3 Ibidem. Por. Произвсдcmвo, http://www.gazprom.ru/about/production/ (accessed: 28.02.2018).
} 


\section{Implementation of the energy policy}

The share of Russian gas in the energy balance of the individual member states of the European Union varies. Post-Soviet and former socialist countries are definitely more dependent on this resource; however, it is also an important segment in the energy balance of the other countries of the European Union. Therefore, many countries, including Poland, have stressed the necessity of reducing dependence on Russia and diversifying imports of energy resources. These actions, however, have not been effective and have faced a negative reaction from Russian authorities, who through the use of various instruments have sabotaged the implementation of some proposals ${ }^{4}$.

Consequently, Russia has strengthened its position in the energy market of the European Union and - in accordance with its energy strategy - has taken action in order to diversify the gas supply routes. From Russia's perspective, a crucial obstacle that prevents the state from strengthening its position in the European energy market is lack of control over the transmission network and the necessity to use transit countries such as Poland and Ukraine ${ }^{5}$.

Therefore, since the collapse of the Soviet Union Russia has been trying to take over Ukraine's strategic pipeline system, which has always been an important factor in the transit of Russian gas to the EU. Ukraine has shown a rather reluctant attitude, therefore Russia decided to launch some ambitious projects to bypass these transit countries $^{6}$. As a result of Russian initiatives, in recent years a few new transmission routes have been put into service to the north (the Baltic Sea) and south (the Black Sea); these have increased Russia's competitive advantage and have weakened the position of transit countries such as Poland and Ukraine.

One of the first investments of the described priorities of diversifying transmission routes was building a gas pipeline called the Blue Stream. It should be stressed that the main purpose of building this pipeline was to extend the transmission route to Turkey, going through Ukraine, Moldavia, Romania and Bulgaria. On 15 December 1997, Russia and Turkey signed an inter-governmental agreement, as part of which Gazprom and Turkish Botas signed a contract to supply 365 billion cu $\mathrm{m}$ of gas within 25 years. The gas was to be supplied by the Blue Stream pipeline, which was yet to

4 Por. J. Techau, Europe Needs to Play the Energy Game With Russia, http://carnegieeurope.eu strategiceurope/54181?lang=en (accessed: 28.02.2018).

5 K. C. Smith, Managing The Challenge Of Russian Energy Policies, p. 6, https://csis-prod. s3.amazonaws.com/s3fs-public/legacy_files/files/publication/101123_Smith_ManagingChallenge_ Web.pdf (accessed: 28.02.2018).

6 Zob. E. Gnedina, M. Emerson, The Case for a Gas Transit Consortium in Ukraine: A Cost-Benefit Analysis, "CEPS Policy Brief" 2009, no. 80, pp. 2-9. 
be built. In February 1999, Gazprom and the Italian ENI signed a letter of intent in order to implement this project. Subsequently, under a joint framework, they registered on 16 November 1999 in the Netherlands a Russian-Italian company, Blue Stream Pipeline Company B.V., which gained ownership over the marine sector of the pipeline. The subsea pipeline was constructed in the period of September 2001 - June 2002 and eventually put into service in November $2005^{7}$.

Considering the volume of exports of the Russian gas to the north, Russia also took the initiative of building a pipeline that would be a direct connection between the Russian pipeline system and the recipients in Germany, and consequently other countries of Western Europe.

The first steps in this matter were taken in 1997-1999, when engineering works were started to build a new gas transmission route underneath the Baltic Sea. Russian research institutes and the Russian-Finnish company, North Transgas, carried out complex research of the sea bottom and confirmed the technical feasibility of building a pipeline through the Baltic Sea area. Over the subsequent years further discussions took place that ended in September 2005. At that time, Gazprom, BASF AG and E.ON AG signed an asset exchange agreement to build this pipeline ${ }^{8}$, while in December 2005 a new company was created, North European Gas Company, which was later renamed Nord Stream AG'.

This investment was sharply criticized by the Polish government, which considered it a direct threat to its political and economic interests. Therefore, Poland called upon other governments and the EU Commission to take action to stop this project.

Regardless of such efforts, in accordance with the Espoo Convention ${ }^{10}$, in November 2006, the company presented information on the project to the relevant authorities of Russia, Finland, Sweden, Denmark and Germany. From 2006 to 2009, contracts were signed to prepare the logistics of the construction. After receiving all necessary permits and bank loans, the executive phase of the project started in April 2010 ${ }^{11}$.

7 This gas pipeline, being 1,213 kilometers long, runs at the bottom of the Black Sea and some sections are placed at a depth of about 2,150 meters. The gas pipeline starts at the Beregovaya station in Russia and runs to the Turkish Samsun, then to Ankara. See: a Голубойnоток», http:// www.gazprom.ru/about/production/projects/pipelines/active/blue-stream/(accessed: 28.02.2018).

8 In December 2007 the Dutch company N.V. Nederlandse Gasunie joined the project.

9 «Северныйпоток», http://www.gazprom.ru/about/production/projects/pipelines/active/nordstream/ (accessed: 28.02.2018).

10 Convention on Environmental Impact Assessment in a Transboundary Context (Espoo, 1991), http:// www.unece.org/fileadmin/DAM/env/eia/eia.htm (accessed: 28.02.2018).

11 Ibidem. 
At that time, Poland constantly criticized the project and tried to stop it by all means. Such steps, however, were not successful, and in 2012 the North Pipeline was eventually put into service. The completion of the project has caused a significant change in the current energy map of the European continent. The North Pipeline avoids transit countries and runs directly at the bottom of the Baltic Sea from Russian Vyborg to German Greifswald. The raw material is then sent through a pipeline network to recipients in the countries in this region, including Denmark, Great Britain, the Netherlands, Belgium, France, and the Czech Republic ${ }^{12}$.

It should be emphasized that the next priority for the Russian Federation in terms of diversification of the energy resource supply routes was an investment in another gas pipeline at the bottom of the Black Sea, which would supply gas to the Balkans and the countries of Southern Europe. Having dealt with all the necessary paperwork, the construction of the Southern Pipeline started in 2013. At that time, however, the Ukrainian crisis took place, as a result of which the European Union and some other countries changed their attitude towards the project. Increasing criticism of energy cooperation with the Russian Federation under these new circumstances caused Russia to eventually decide to step back from implementing the project in $2015^{13}$. The fact that Russia officially gave up the Southern Pipeline project did not, however, stop attempts to build a new route in this direction. Russia, in close cooperation with Turkey, decided to build a new gas pipeline, the Turkish Stream ${ }^{14}$.

12 Nord Stream is 1,224 kilometers long. It consists of two corridors of total capacity of 55 bn cu $\mathrm{m}$ ( $27.5 \mathrm{bn}$ cu $\mathrm{m}$ each). The project implementation was divided into two stages. In April 2010, the construction of the first section commenced and it was finished in May 2011. In June 2011 the construction of the second corridor started and it was finished in April 2012. An estimated cost of building the subsea pipeline was 7.4 bn EUR. 30\% of the project costs came from shareholders, proportionally to their shares in the project: Gazprom - 51\%, BASF SE/Wintershall Holding GmbH - 15.5\%, E.ON Ruhrgas AG - 15.5\%, N.V. Nederlandse Gasunie - 9\%, GDF Suez S.A. - 9\%. See: Проекm Nord Stream, https://www.nord-stream.com/ru/proekt/gazoprovod-severnyipotokJ (accessed: 21.02.2018); „Северный поток». Газопровод, напрямую соединивиий Россию и Eвpony, http://www.gazprom.rw/projects/nord-stream/ (accessed: 21.02.2018); Энергия для Eвponы. Проекm Nord Stream, https://www.nord-stream.com/ru/ (accessed: 21.02.2018).

13 Putin blames EU as Russia abandons plans for South Stream gas pipeline, The Guardian, 1.12.2014, https://www.theguardian.com/business/2014/dec/01/russia-blames-eu-as-it-abandons-plans-forsouth-stream-gas-pipeline (accessed: 21.02.2018). The length of the subsea sector was supposed to be 900 kilometers and, similarly to the Blue Stream, some of the pipes were to be placed at a depth of 2,250 meters. See: «Южный поток", https://web.archive.org/web/20090830220041/ http://www.gazprom.ru:80/production/projects/pipelines/south-stream/ (accessed: 21.02.2018).

14 K. Rapoza, Fearing Global Sanctions, Russia Speeds Up Turkish Stream Gas Pipeline, "Forbes", 20.07.2017, https://www.forbes.com/sites/kenrapoza/2017/07/20/fearing-global-sanctions-russiaspeeds-up-turkish-stream-gas-pipeline/\#201d095658c5 (accessed: 21.02.2018). 


\section{The alternative direction of cooperation}

As already mentioned, as a result of the annexation of Crimea, as well as Russia's involvement in the conflict in the eastern parts of Ukraine, some significant changes in energy cooperation have arisen between the EU and Russia. Considering the imposition of sanctions against Russia after the annexation of Crimea, some EU leaders indicated the need to take action to make the EU less dependent on the import of raw materials from Russia.

The Polish Prime Minister, Donald Tusk, presented the idea of creating an Energy Union. The project would strengthen the EU's negotiating position in several ways: 1) joint purchasing of energy; 2) launching a gas solidarity mechanism when supplies are withheld; 3) increased use of coal in the EU energy balance; 4) investments in shale gas; 5) diversification of energy and gas resources; and 6) increasing financial contributions to the energy infrastructure that would support solidarity and cooperation between EU countries in case of a potential crisis ${ }^{15}$.

Reacting to the above actions of the EU, Russian authorities stressed that they are a predictable partner that would ensure stable supplies of raw materials to the member states. At the same time, Gazprom representatives emphasized that Russia does not depend on supplies to the European market and can also significantly diversify exports by supplying the energy-intensive market in $\mathrm{China}^{16}$.

The above statements were soon confirmed by signing a gas supply contract with China on 21 May 2014 in Shanghai. This decision was a gesture by the Kremlin which proved to its western partners that Russia does not depend on exports of gas to the European market. It should also be treated as a political reward for China's attitude towards the Ukrainian crisis. It should be emphasized here that - as a permanent member of the UN Security Council - China did not take a clear position on the annexation of Crimea. On 27 March 2014, during a General Assembly vote on a resolution criticizing Russia for the annexation of the peninsula, China also abstained from voting, which can be considered as a silent approval for the actions of the Russian Federation ${ }^{17}$.

15 PM Tusk outlines vision for EU energy union, "Radio Poland", 29.03.2014, http://www.thenews. $\mathrm{p} /$ 1/9/Artykul/166793,PM-Tusk-outlines-vision-for-EU-energy-union (accessed: 21.02.2018).

${ }^{16}$ D. Dyomkin, Russia can find niche in Asian gas market: Putin, "Reuters", 17.07.2013, https:// www.reuters.com/article/us-russia-gas-asia/russia-can-find-niche-in-asian-gas-market-putinidUSBRE96G0D920130717 (accessed: 21.02.2018).

17 P. Bajor, Azja a sprawa ukrainska, "New Eastern Europe”, 18.07.2014, http://www. new.org. $\mathrm{pl} / 1879$,post.html (accessed: 21.02.2018). 
Therefore, the signing of the contract between Gazprom and NPCH, which had been negotiated for over 10 years, was a direct consequence of the conflict in Ukraine and has significantly changed the priorities of Russia's energy policy. The signed document assumes that Gazprom, using the Power of Siberia pipeline, will supply 38 bn cu m of gas annually to China for 30 years. Gazprom authorities also emphasized that the EU is not a priority for them, and the potential decrease in supplies to the European market will be compensated for by increasing exports to Asian countries. At the same time, at the APEC summit in Beijing on 9 November 2014, Gazprom and CNPC signed another framework agreement on gas supplies, on the basis of which both countries expressed their willingness to build a second gas pipeline to the western part of China that within the next 30 years will supply $30 \mathrm{bn}$ cu $\mathrm{m}$ of gas per year ${ }^{18}$.

\section{Global strategy}

A key role in the Russian Federation's energy policy is played by Gazprom and its subsidiaries that deal with exploration, purification, and transporting the raw materials. In accordance with Gazprom's strategy, a key mission is to transform the company into a global enterprise that will play a crucial role in global markets. In order to accomplish this, the strategy assumes market diversification, including regional markets, and ensuring stable supplies to recipients ${ }^{19}$.

Exportation of Russian gas to China, planned for 2019, will mean the opening of a new stage in Russia's energy policy. Russia has tried to access the lucrative, energy-intensive Chinese market for many years, but negotiations always ended up with nothing as a result of a deep difference of opinion on resource prices. As already mentioned, in 2014, facing critical relations with the European Union, Putin decided to make some concessions, and a ground-breaking contract between Russia and China was eventually signed ${ }^{20}$.

From the perspective of Russia's interests, entering the Chinese market has a significant value. Many forecasts estimate that the usage of gas in China will keep increasing, and demand for Russian resources will also be higher. Therefore, Russia's

18 Ibidem; S. Kardaś, The 'new' arrangements in Russian-Chinese energy cooperation, Centre for Eastern Studies, 19.11.2014, https://www.osw.waw.pl/en/publikacje/analyses/2014-11-19/newarrangements-russian-chinese-energy-cooperation (accessed: 21.02.2018).

19 Cтратегия Газпрома, http://www.gazprom.ru/about/strategy/ (accessed: 21.02.2018). See also: Алексей Миллер провел селекторное совещание, посвященное 25-летию „Газпрома", http:// www.gazprom.nu/press/news/miller-journal/2018/918665/ (accessed: 21.02.2018).

20 P. Bajor, op. cit. 
and Gazprom's positions in the Chinese market may improve, and subsequently Russia may gain an important tool in bilateral relations. China, however, has drawn lessons from seeing the political consequences of some countries becoming too dependent on Russian resources. Therefore, China's priority in terms of energy policy is to diversify its suppliers and import resources ${ }^{21}$.

A significant role in Russia's global strategy is played by the Southeastern Asia and Pacific regions. Russia supplies these markets with liquefied gas that goes to Japan, Taiwan and South Korea. Another destination of gas supplies is India. A confirmation of Gazprom's global strategy is the planned increased presence in more remote markets and sending liquefied gas to South America and the Middle East, among others to Kuwait and the United Arab Emirates. In order to increase the export possibilities of liquefied gas, Russia decided to launch a new investment and build a new liquefied gas terminal in the area of Sankt Petersburg. To implement this project, Gazprom signed a necessary agreement with Shell and analyses of the project and the terms of building a terminal of a capacity of 10 million tons per year are ongoing ${ }^{22}$.

It should also be emphasized that the idea of creating an Energy Union and purchasing Russian gas within the European Union has not been implemented. Therefore, Gazprom's position has not been endangered and has even strengthened in some countries as a result of increased demand for Russian gas. Germany, being the biggest importer of gas, also decided to resume cooperation with Russia on the investment in the Northern Pipeline-2. This to a large extent influences the European Union's solidarity in terms of energy policy and interferes with some basic economic interests of Poland. Therefore, Polish authorities constantly criticize this investment. Considering, however, the solid position and economic interests of Germany and Russia, nothing indicates that Poland will be able to stop this investment from being implemented $^{23}$.

\section{Ibidem.}

22 Новые рынки, http://www.gazpromexport.ru/strategy/markets/ (accessed: 21.02.2018).

23 E. King, German and Polish leaders clash over Nord Stream 2 pipeline, "Politico", 16.02.2018, https:// www.politico.eu/article/nord-stream-2-german-and-polish-leaders-clash/ (accessed: 21.02.2018); Poland says Nord Stream 2 would harm regional security, "Daily Mail”, 18.12.2017, http://www. dailymail.co.uk/wires/ap/article-5190901/Polands-PM-Nord-Stream-2-harmful-region.html (accessed: 21.02.2018). 


\section{Summary}

Analyzing Russia's energy policy, it should be stated that it is subordinated to the state's foreign and security policy and is a crucial factor in its implementation. Using energy policy instruments, Russia tries to strengthen its position in particular markets and consequently plays a significant role in them in terms of politics. It is worth mentioning that, as a result of the Ukrainian crisis of 2014, the cooperation between Russia and some European Union countries has been drastically set back; however, it has gradually been restored, the best confirmation of which is the building of the Northern Pipeline-2. Its completion will strengthen Russia's competitive advantage in the European market and will lead to the further weakening of transit countries such as Poland. In the longer term Russia will take further action to strengthen its position in particular markets, both as a gas exporter and as a shareholder in relevant energy sector companies. Such action is related to Russia's interests and the priorities of its energy policy, in which the European market plays a very important role. It should be stressed, however, that by implementing a global strategy Russia will diversify exports and will take the same steps as part of its expansion towards new outlets in different regions of the world, at the same time, pursuing the key principle of its foreign policy; namely, confirming its superpower status and being a country of global standing.

\section{References}

\section{Documents}

Convention on Environmental Impact Assessment in a Transboundary Context (Espoo, 1991), $\mathrm{http}: / / \mathrm{www} . u n e c e . o r g /$ fileadmin/DAM/env/eia/eia.htm (accessed: 28.02.2018).

Энергетическая стратегия России на период до 2030 года утверджена распоряжением Правительства Российской Федерачии от 13 ноября 2009 2. № 1715-p, https:// minenergo.gov.ru/node/1026 (accessed: 21.02.2018).

\section{Reports}

Gnedina, E., Emerson, M. The Case for a Gas Transit Consortium in Ukraine: A Cost-Benefit Analysis, “CEPS Policy Brief” 2009, no. 80.

\section{Internet sources}

Алексей Миллер провел селекторное совещание, посвященное 25-летию “Газпрома", httр:// www.gazprom.ru/press/news/miller-journal/2018/918665/ (accessed: 21.02.2018).

Bajor, P. Azja a sprawa ukraiñska, "New Eastern Europe”, 18.07.2014, http://www. new.org. $\mathrm{pl}$ 1879,post.html (accessed: 21.02.2018). 
Dyomkin, D. Russia can find niche in Asian gas market: Putin, "Reuters", 17.07.2013, https:// www.reuters.com/article/us-russia-gas-asia/russia-can-find-niche-in-asian-gas-marketputin-idUSBRE96G0D920130717 (accessed: 21.02.2018).

Энергия для Eвропы. Проект Nord Stream, https://www.nord-stream.com/ru/ (accessed: 21.02.2018). "Голубойпоток", http://www.gazprom.ru/about/production/projects/pipelines/active/bluestream/ (accessed: 28.02.2018).

«Южныйпоток", https://web.archive.org/web/20090830220041/http://www.gazprom.ru:80/ production/projects/pipelines/south-stream/ (accessed: 21.02.2018).

Kardaś, S. The 'new' arrangements in Russian-Chinese energy cooperation, Centre for Eastern Studies, 19.11.2014, https://www.osw.waw.pl/en/publikacje/analyses/2014-11-19/newarrangements-russian-chinese-energy-cooperation (accessed: 21.02.2018).

King, E. German and Polish leaders clash over Nord Stream 2 pipeline, "Politico", 16.02.2018, https://www.politico.eu/article/nord-stream-2-german-and-polish-leaders-clash/ (accessed: 21.02.2018).

Новыерынки, http://www.gazpromexport.ru/strategy/markets/ (accessed: 21.02.2018). $P M$ Tusk outlines vision for EU energy union, "Radio Poland", 29.03.2014, http://www. thenews.pl/1/9/Artykul/166793,PM-Tusk-outlines-vision-for-EU-energy-union (accessed: 21.02.2018).

Poland says Nord Stream 2 would harm regional security, "Daily Mail”, 18.12.2017, http:// www.dailymail.co.uk/wires/ap/article-5190901/Polands-PM-Nord-Stream-2-harmfulregion.html (accessed: 21.02.2018).

Проекm Nord Stream, https://www.nord-stream.com/ru/proekt/gazoprovod-severnyi-potok/ (accessed: 21.02.2018).

Производство, http://www.gazprom.rw/about/production/ (accessed: 28.02.2018).

Putin blames EU as Russia abandons plans for South Stream gas pipeline, The Guardian, 1.12.2014, https://www.theguardian.com/business/2014/dec/01/russia-blames-eu-asit-abandons-plans-for-south-stream-gas-pipeline (accessed: 21.02.2018).

Rapoza, K. Fearing Global Sanctions, Russia Speeds Up Turkish Stream Gas Pipeline, "Forbes", 20.07.2017, https:/www.forbes.com/sites/kenrapoza/2017/07/20/fearing-globalsanctions-russia-speeds-up-turkish-stream-gas-pipeline/\#201d095658c5 (accessed: 21.02.2018).

"Северныйпоток», http://www.gazprom.ru/about/production/projects/pipelines/active/ nord-stream/ (accessed: 28.02.2018).

"Северныйпоток". Газопровод, напрямую соединивщий Россию и Европу, http://www. gazprom.ru/projects/nord-stream/ (accessed: 21.02.2018).

Smith, K. C. Managing The Challenge Of Russian Energy Policies, https://csis-prod. s3.amazonaws.com/s3fs-public/legacy_files/files/publication/101123_Smith_ ManagingChallenge_Web.pdf (accessed: 28.02.2018).

Cтратегия Газпрома, http://www.gazprom.ru/about/strategy/ (accessed: 21.02.2018).

Techau, J. Europe Needs to Play the Energy Game With Russia, http://carnegieeurope.ew/ strategiceurope/54181?lang=en (accessed: 28.02.2018). 